\title{
Expanded commuting in the metropolitan region of Belo Horizonte: evidence for reverse commuting ${ }^{\star}$
}

\author{
Carlos Lobo** \\ Ralfo Matos ${ }^{\star * \star}$ \\ Leandro Cardoso ${ }^{\star * \star *}$ \\ Lídia Comini ${ }^{\star \star \star \star \star}$ \\ Guilherme Pinto ${ }^{\star \star \star \star \star \star}$
}

Large Brazilian cities, particularly those that have experienced rapid population growth since the middle of the last century, have exhibited significant signs of population dispersion in their peripheries in recent decades. A study of the population's spatial redistribution in the Metropolitan Region of Belo Horizonte (MRBH) confirms this finding. In the process of dispersion, the levels of urban commuting increase, and commuting becomes a relevant indicator of the degree of integration within the metropolis. This paper evaluates the current magnitude and main features of reverse commuting, as characterized by the daily displacements of the population that resides not in the periphery but rather in the core. Flows from the metropolitan core towards the peripheral municipalities are examined using sample microdata on the MRBH municipalities from the 2000 and 2010 demographic censuses by combining the variables of "municipality of residence" and "municipality of work/study." The results indicate an increase in reverse commuting in both absolute and relative terms. When this flow is compared to traditional commuting (periphery/center), the relative values are considerable. In some cases, this relationship reaches notably high values, as the case of Confins (the municipality where the international airport is located), and also municipalities that are part of a relatively old conurbation, such as Nova Lima and Betim.

Keywords: Reverse commuting. Metropolitan Region of Belo Horizonte. Spatial dispersion of the population.

\footnotetext{
* This paper reports results that are part of the research projects "The migrations and commuting of the population in Belo Horizonte's region of influence" and "The spatial mobility of the population in the Metropolitan Region of Belo Horizonte," funded by the Foundation to Support Research in Minas Gerais (Fundação de Amparo à Pesquisa do Estado de Minas Gerais - Fapemig) and the National Council for Scientific and Technological Development (Conselho Nacional de Desenvolvimento Científico e Tecnológico - CNPq). Acknowledgement is also due the Dean of UFMG for financial support.

${ }^{* *}$ Department of Geography at the Geoscience Institute, Universidade Federal de Minas Gerais, Belo Horizonte-MG, Brazil (carlosfflobo@gmail.com).

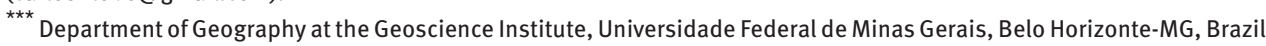
(ralfomatos@gmail.com).

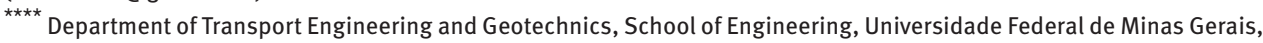
Belo Horizonte-MG, Brazil (leandrocardoso@ufmg.br).

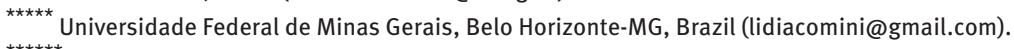

${ }^{\star \star \star \star \star \star}$ Universidade Federal de Minas Gerais, Belo Horizonte-MG, Brazil (guilhermefnp2@gmail.com).
} 


\section{Introduction}

Since the 1980s, the deconcentration of population and economic activities has attracted the attention of researchers studying the spatial redistribution of the population in Brazil. Debates on the subject have resulted in the wider use of terms such as "demetropolitanization”, "polarization reversal”, "concentrated deconcentration", and "spatial dispersion". Also, there is empirical evidence that the decline in population growth that occurred in various Brazilian metropolitan centers in recent decades is attributable to various causes, including center-periphery migration.

Although the urbanization process in Brazil is relatively recent, some authors, using data from the last two censuses, have found evidence of spatial dispersion, even though the major cities have maintained a strong regional/national demographic expression and continue to attract thousands of migrants from depressed regions, albeit with very low growth (MARTINE, 1994; DINIZ, 1993; MATOS, 1995a; LOBO, 2009; LOBO; MATOS, 2011).

Data on population mobility within the Metropolitan Region of Belo Horizonte (MRBH) confirm this trend. Several studies have shown that, since the 1970 s, many municipalities in the metropolitan periphery experienced strong population growth, largely as a result of the high volume of migration from the metropolitan core. These migratory flows also reflect the distribution of wealth production in the region, which can be confirmed by a loss of relative participation in Belo Horizonte's GDP in recent decades (LOBO; CARDOSO; MATOS, 2009).

Notwithstanding the contributions already made by regional economic and demographic analyses, this phenomenon requires further research in terms of the possible consequences of the population's spatial redistribution and the mobility of the residents of the Metropolitan Region of Belo Horizonte's (MRBH). In the field of geography, studies of these movements remain few, as do studies that explore questions arising from the censuses carried out by the Brazilian Institute of Geography and Statistics (Instituto Brasileiro de Geografia e Estatística - IBGE).

The purpose of this paper is to assess the metropolitan core's level of centrality, based on the population's daily movements to and from the 33 municipalities of the Metropolitan Periphery (MP) of Belo Horizonte, located in central Minas Gerais state (Figure 1).

For this study, sample microdata from the 2000 and 2010 demographic censuses were used, allowing the identification of specific "place of residence to place of work/ study" movements comprising commuting in the MRBH. The two variables that separately identified the workplace and study place from the current residence in the 2010 Census were combined, giving priority to the municipality of work when it was different from the place of study. This merging was necessary for comparison with the 2000 Census data, which inquire in one question the place of study or work. An analysis of the volumes of these flows, to work/study from and to Belo Horizonte, allowed a problematization of commuting in order to examine urbanization and intra-metropolitan spatial dispersion. 
FIGURE 1

Municipal division of the Metropolitan Region of Belo Horizonte, Minas Gerais, Brazil - 2000-2010

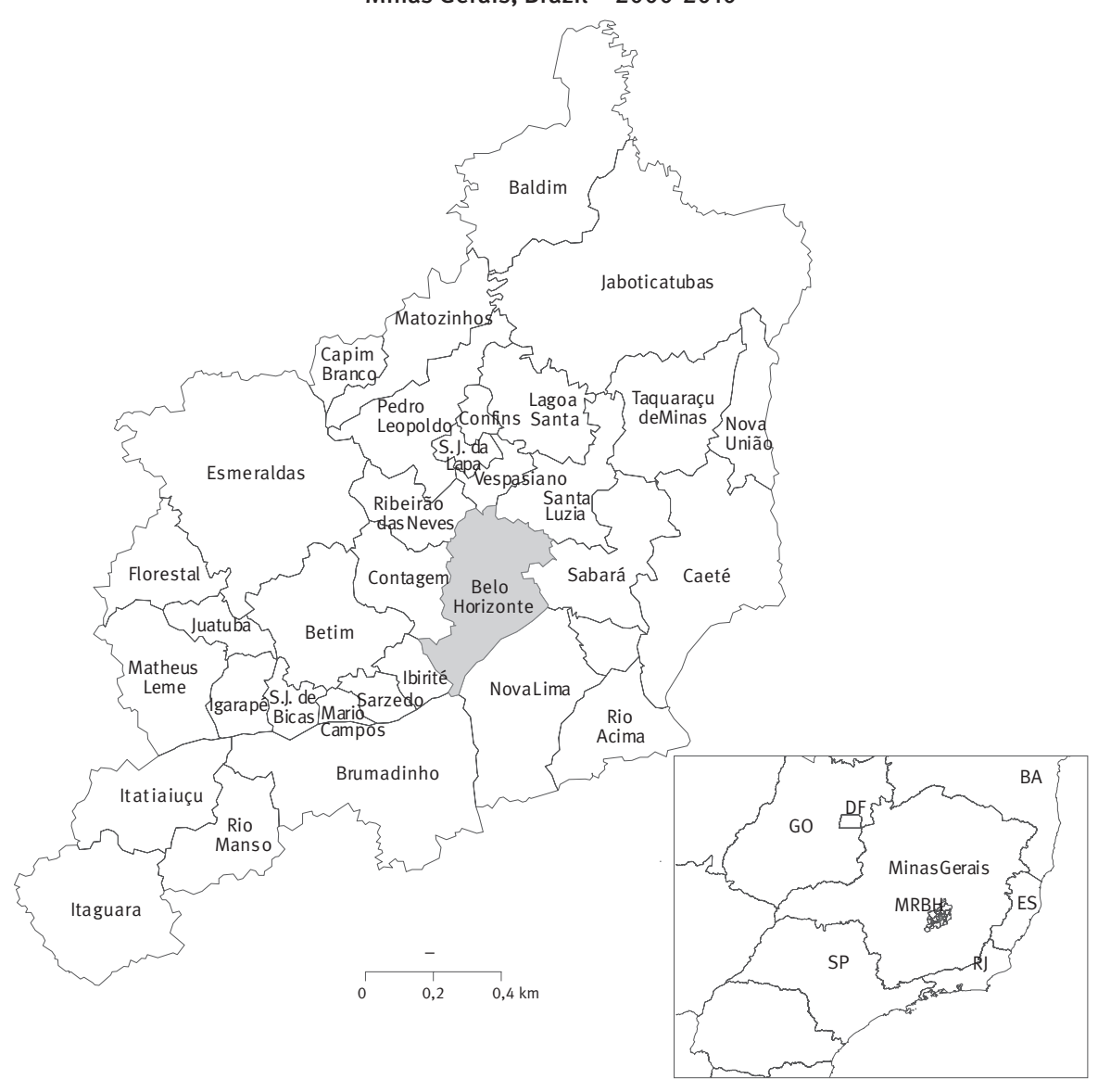

\section{Population deconcentration and/or dispersion: a brief review of the literature}

Richardson (1980), one of the first authors to discuss the issue of polarization reversal, observed that a continued increase in concentration does not lead to a continued increase in economic efficiency. The marginal benefits derived from urban scale and concentration tend to decrease after a certain population size has been reached. This process is characterized by a change in the spatial polarization trend in the national economy, from the point at which spatial dispersion occurs outside the central region. Richardson believed that polarization reversal occurs in a series of stages: first, there is a well-defined process of economic concentration, in which a center and periphery have been established; then, structural changes take place in the center, with the adjacent cores beginning to undergo more rapid growth than the center; the third stage marks the beginning of the polarization reversal process, with expanded dispersion; then, the dispersion also 
reaches the secondary centers; and, finally, the center begins to lose population. Thus, as employment opportunities begin to expand more rapidly outside the main metropolitan area, the residential population tends to redistribute itself throughout the urban system, reflecting the increasing comparative advantages of the secondary cities. Capital and labor flows converge outside the central metropolis in secondary cities that experience relatively faster rates of economic and demographic growth.

In the field of regional studies, there have been various attempts to apply these models and theoretical reconstruction in Brazil, where structural and sectoral particularities make it difficult to interpret this phenomenon. One of the first studies of the possible process of polarization reversal in Brazil was by Townroe and Keen (1984). In considering this process from the point at which the urban population's concentration in the central region begins to decrease, these authors believed that there were concrete signs of polarization reversal in the state of São Paulo between 1970 and 1980. They suggested a duality in the factors that lead to the concentration of economic activities, highlighting the concentrative role played by certain social and economic forces, which at a certain point begin to act in the opposite direction, towards deconcentration. Demographic transition, the degrees of social and economic inequality, the patterns of rural development, and the institutional and social forms of disseminating information and innovations may or may not increase the concentration of an urban population's distribution.

Although the notion of polarization reversal is attractive and may seem consensual, the findings on polarization reversal in Brazil encountered numerous criticisms. These ranged from questioning the empirical evidence that was used, to the type of variables and the methodologies that were adopted. Azzoni (1986), for example, criticizes the fact that a city's size is considered an indicator of agglomerative economies. In admitting that these advantages, as with psychological polarization and the transport of ideas, are present in the urban environment, it is essential to consider the region as capable of generating a field of attraction for new investments. The basic idea is that regional attraction transcends the urban environment, while the locational costs are essentially urban. The assumption that there would be a process of polarization reversal in Brazil in the 1970 s would be, at the least, premature. Evidence indicated that, far from being a sign of polarization reversal, the phenomenon observed in São Paulo would be more akin to a sprawling of industry within the most industrialized area of the country, a process of "concentrated deconcentration" (AZZONI, 1986).

In challenging some of the assumptions and results presented by Azzoni, Diniz (1993) offers a new model of interpretation. He believes that following the undisputed economic and demographic concentration observed to the end of the 1960s, the initial stages of the process of reversing this polarization began. However, the deconcentration process would not have occurred widely, but rather in certain areas that were well equipped and rich in externalities, which is reflected in the sprawl towards the interior of certain Brazilian states. Meanwhile, Negri (1996) considers Azzoni's analogy inapt, and also believes that the 
polygon established by Diniz is inappropriate. According to Negri, although this region has benefited from the deconcentration of the last 20 years, which expanded its participation in the national industry from $33.1 \%$ to $49.2 \%$, the deconcentration was not incompatible with growth outside the polygon. ${ }^{1}$

Rapid urban growth has been characteristic of Brazil since the 1940s. The nascent industrial economy began to redefine the paths of territorial reorganization, and the new pattern of urbanization was essentially concentrative. The population's internal redistribution intensified, largely in favor of great urban centers, especially those located in the Southeast region. In parallel, government programs had incentivized successive openings of agricultural frontiers since the 1930s (MARTINE, 1987; PATARRA, 1984; TASCHNER; BÓGUS, 1986). The growth rates of the urban population, particularly from 1950 on, were very high. They only began to slow in the 1970s, a time when the rural exodus was still significant and the excessive demographic concentration in Brazil's Southeast region became a concern to local authorities and governments. At that time, more than $72.0 \%$ of the Southeast's population resided in urban areas, and, gradually, accelerated urbanization began in other regions. It is clear that increased rural-urban migratory flows strongly contributed to the urbanization process. Brazil's largest capital cities centralized urban regions that seemed to emerge as a single organism, a single city, although subordinate to different municipal administrations. As such, the federal government mandated the creation of Metropolitan Regions (MRs) so that the political and administrative links between the municipalities within these sub-areas could resolve shared problems. ${ }^{2}$ State and federal funding was given as an incentive for integrated management to cities that participated in developing and planning this new management model. Eight of the nine major MRs in Brazil were created in 1973 (São Paulo, Belo Horizonte, Porto Alegre, Recife, Salvador, Curitiba, Belém, and Fortaleza), with Rio de Janeiro added in 1974.

\section{The dispersion and daily spatial movements of the MRBH's population}

Since the 1970s, as Rigotti (1999), Rigotti and Rodrigues (1994), and Matos (1995a), among others, have demonstrated, there has been a noticeable deceleration in Belo Horizonte's growth rate. From then on, the municipalities on the MRBH's periphery experienced much more significant population increases than the capital city itself. The

\footnotetext{
${ }_{1}^{1}$ For Matos (1995b), important changes in the population's spatial distribution are ongoing, without knowing, however, the true extent of the phenomenon or whether existing theories can explain these cases. It is, however, indisputable that much of the expansion of Brazil's urbanization in recent decades derives from the multiplying effects of the Southeast's sprawling urban and industrial concentration. This process encouraged a consolidation of the urban network and the links of complementarity between the urban centralities.

${ }^{2}$ It is worth noting that, even in the 1960s, in many states the government was heading in that direction, recognizing the metropolitan issue and putting nascent experiences of inter-municipal management into practice. This contributed to the inclusion of the metropolitan issue in the 1967 Federal Constitution, and to its continued presence in Constitutional Amendment no. 1, of 1969. Thus, soon after the promulgation of the 1967 Constitution, studies to define criteria for the administrative demarcation and organization of metropolitan regions began, culminating in their institutionalization six years later.
} 
peripheral municipalities witnessed annual population growth rates of $6.84 \%, 5.01 \%$, and $4.40 \%$ in the periods of $1970 / 1980,1980 / 1991$, and $1991 / 2000$, respectively. In these same periods, the municipality of Belo Horizonte had annual growth rates of $3.73 \%$, $1.15 \%$ and $1.10 \%,{ }^{3}$ respectively. These differences in the growth rates of the metropolitan periphery were reflected in the evolution of the metropolitan core's participation in the MRBH's total population stocks. Since 1970, the metropolitan periphery has grown in demographic volume and increased its relative participation in the MR. In 2000, 48.63\% of the metropolitan region's population resided outside Belo Horizonte (in 1970, it was only $33.59 \%)$.

This decline in Belo Horizonte's population participation could lead to at least two seemingly contradictory conclusions: a loss of the capital city's centrality or an expansion of the metropolitan core's field of polarization. The first hypothesis is based on a probable displacement of economic activities and population from the core to the periphery, with a reduction in the capital city's economic and demographic weight. In the other, the periphery's growth is observed as a result of the outflow from the metropolitan core, which, contrary to what one might think, would represent increased polarization and densification of the core regional urban network. Although it seems contradictory, an analysis of the population's mobility between the core and the municipalities of the metropolitan periphery appears to indicate that, even though Belo Horizonte has maintained its centrality, a reasonable number of municipalities in the region have gained autonomy. Various municipalities that were described as mere "sleeper cities" in the 1960s and $1970 s^{4}$ have both expanded their interrelationships with the core and undergone a strong development of certain eminently urban features. This has led a growing portion of the local population to carry out their economic/professional activities in their municipality of residence, which tends to impact the proportion or volume of those moving daily between the periphery and metropolitan core.

Regardless, intra-metropolitan mobility has become a good indicator of the degree of interaction between municipalities because it reflects the social density of the constructed metropolitan area, alluded to by various urban studies of the intensification of daily urban commuting in the municipalities of a metropolitan area (ANTICO, 2004; MOURA et al., 2005; ARANHA, 2005; OJIMA et al., 2014). In the case of the MRBH, as with the other major metropolitan agglomerations in Brazil, these movements have primarily resulted from the shift of real estate capital, along with specific state allocations for economic infrastructure and housing programs. However, the wealthiest households in the capital city continue to

\footnotetext{
3 Inter- and intra-regional migratory flows played an important role in the decline in Belo Horizonte's growth rate. After the 1970/1980 period, as Rigotti (1994) indicated, net migration rates were already favoring the metropolitan periphery, with notable population gains in the municipalities of Ribeirão das Neves, Betim, Contagem, Ibirité, Santa Luzia, and Vespasiano.

${ }^{4}$ An explanation of this process is provided by Ojima and colleagues who use the term "sleeper city" has been linked to the processes of marginalizing and peripheralizing poverty in metropolitan contexts. These are cities created through significant migration growth households to municipalities farther away from their place of work, in search of better environmental quality, less violence, etc.” (OJIMA et al., 2014)
} 
utilize services provided by the low-income population. ${ }^{5}$ Many of these service providers undoubtedly commute within the $\mathrm{MRBH}$, though the flow of residents from the center towards the metropolitan periphery should be increasing. Studies that seek to understand the logic underlying the disproportionate growth of urban areas in conurban municipalities are old and recurrent. The growing distances between place of residence and place of work, imposed by the exclusionary dynamic of the housing market and discriminatory urban policies, constitute one of the major socioeconomic problems of large Brazilian cities, and are even at the root of the large protests happening currently, whether peaceful or violent. ${ }^{6}$

The more specific research, such as the Origin-Destination Survey, provides data on the flows of people within a single agglomeration, which allows the visualization of the complexity of movements resulting from interactions between people and employmentgenerating sites in major Brazilian urban centers. However, it is also possible to measure daily movements between municipalities with demographic census data, specifically with the question of the municipality in which the person works and/or studies (MATOS; FERREIRA, 2004; LOBO; CARDOSO; MATOS, 2009).

\section{Reverse commuting: the new face of dispersion? Evidence based on flows in the MRBH}

The economic and demographic expansion of metropolitan cores explains the increased strength of their polarization. Although this is not a new phenomenon, it can be measured through commuting. One recurring piece of evidence of the population's daily movements comes from residents in the peripheries who go to work or study in the metropolitan centers. However, because of the direct and indirect effects of "(dis) economies of agglomeration" (still in the stage of disseminating positive gains in productive agglomeration), new centralities located in the periphery begin to attract population, including people coming from the metropolitan core. The data shown in Table 1 present two periods (from the last two censuses) and confirm this hypothesis.

Although the flow from the periphery to the core of the metropolitan area has increased (from 226,957 to 382,130 ), the growth of flow toward the periphery was considerably higher: from 39,543 in 2000 to 69,903 people in 2010 (an increase of $76.73 \%$, compared to $43.35 \%$ for Traditional Commuting). It appears that there was a significant increase in daily mobility in the Metropolitan Region of Belo Horizonte, especially by capital city residents. Observing the proportion represented by Reverse Commuting (RC) - referring to centerto-periphery flows - over Traditional Commuting (TC) - referring to periphery-to-center flows - the results confirm the growth of metropolitan mobility towards the periphery. If RC corresponded to $8.61 \%$ of TC in 2000 , in 2010 this ratio reached $11.30 \%$. Moreover,

\footnotetext{
$\overline{5}$ Brito and Souza (2005), taking the MRBH as an example, assert that inequality in the metropolitan space's social fabric can be understood from the fact that nearly $70 \%$ of those who commute to work in Belo Horizonte used to reside in that city; in some municipalities, the proportion is higher, as is the case in Sabará. Thus, intra-metropolitan migration is largely associated with the movement of real estate capital and the selectivity of migration.

${ }^{6}$ More details about these protests see Singer (2013).
} 
in some municipalities the ratio between RC and TC experienced considerable growth. In relative terms, the most significant case is Confins, whose RC/TC proportion in 2010 was greater than $300 \%$ and more than three times of what it was in 2000 . In this case, most of the commuting changes for this municipality were a direct consequence of the resumption/ expansion of activities at the Tancredo Neves International Airport. In other municipalities with significant volumes of commuters, such as Contagem, Betim, and Nova Lima, the RC/ TC proportion is also relatively high. In the latter two, this ratio was approximately $50 \%$ in 2010 , which means that for every two people living in these municipalities and working or studying in Belo Horizonte, one person makes the opposite journey. In 2010, the number of people who work or study in Contagem and live in Belo Horizonte was 30,201 (in 2000 this number was 19,975 people), and the RC/TC ratio was $34.02 \%$.

As shown in Figure 2, the RC/TC ratio was less than $10 \%$ in most of the metropolitan periphery's municipalities in 2000, an observation that is valid for 18 of the 34 municipalities listed. In 2010, only 12 municipalities had such low ratios. The proportional growth of Reverse Commuting occurs in the municipalities on the north axis (Santa Luzia, Ribeirão das Neves and São José da Lapa) and the suburbs of the east (Sabará, Raposos and Caetés), west (Capim Branco, Esmeraldas and Florestal) and south (Ibirité, Mário Campos and Itatiaiuçu).

TABLE 1

Traditional commuting (TC) and reverse commuting (RC) in the Metropolitan Region of Belo Horizonte, based on flows from and to Belo Horizonte $-2000-2010$

\begin{tabular}{|c|c|c|c|c|c|c|}
\hline \multirow{2}{*}{ Municipalities } & \multicolumn{3}{|c|}{2000} & \multicolumn{3}{|c|}{2010} \\
\hline & TC & $\mathrm{RC}$ & Difference & $\mathrm{TC}$ & $\mathrm{RC}$ & Difference \\
\hline Baldim & 104 & 20 & 85 & 124 & 59 & 65 \\
\hline Betim & 19.224 & 8.411 & 10.813 & 28.180 & 13.942 & 14.238 \\
\hline Brumadinho & 1.461 & 259 & 1.202 & 2.134 & 429 & 1.704 \\
\hline Caeté & 2.132 & 77 & 2.054 & 2.874 & 167 & 2.707 \\
\hline Capim Branco & 211 & 11 & 201 & 250 & 20 & 230 \\
\hline Confins & 113 & 136 & -23 & 238 & 723 & -485 \\
\hline Contagem & 69.504 & 19.975 & 49.530 & 88.772 & 30.201 & 58.570 \\
\hline Esmeraldas & 3.035 & 145 & 2.890 & 6.109 & 375 & 5.733 \\
\hline Florestal & 40 & 51 & -10 & 181 & 0 & 181 \\
\hline Ibirité & 23.351 & 1.508 & 21.843 & 35.378 & 2.279 & 33.098 \\
\hline Igarapé & 402 & 99 & 303 & 728 & 167 & 561 \\
\hline Itaguara & 151 & 7 & 144 & 193 & 23 & 170 \\
\hline Jaboticatubas & 265 & 18 & 247 & 636 & 136 & 500 \\
\hline Juatuba & 389 & 137 & 252 & 673 & 111 & 562 \\
\hline Lagoa Santa & 1.977 & 661 & 1.316 & 4.530 & 1.097 & 3.433 \\
\hline Mário Campos & 826 & 20 & 806 & 1.260 & 46 & 1.213 \\
\hline Mateus Leme & 574 & 34 & 540 & 732 & 74 & 659 \\
\hline Matozinhos & 832 & 94 & 737 & 1.073 & 220 & 853 \\
\hline Nova Lima & 7.494 & 1.749 & 5.745 & 13.475 & 6.759 & 6.717 \\
\hline
\end{tabular}


(Continuação)

\begin{tabular}{|c|c|c|c|c|c|c|}
\hline \multirow{2}{*}{ Municipalities } & \multicolumn{3}{|c|}{2000} & \multicolumn{3}{|c|}{2010} \\
\hline & TC & $\mathrm{RC}$ & Difference & TC & $\mathrm{RC}$ & Difference \\
\hline Nova União & 240 & 0 & 240 & 205 & 71 & 135 \\
\hline Pedro Leopoldo & 1.841 & 388 & 1.453 & 3.139 & 717 & 2.422 \\
\hline Raposos & 1.768 & 21 & 1.747 & 2.526 & 84 & 2.441 \\
\hline Ribeirão das Neves & 52.579 & 1.923 & 50.657 & 76.322 & 4.006 & 72.317 \\
\hline Rio Acima & 450 & 28 & 422 & 829 & 123 & 706 \\
\hline Rio Manso & 45 & 21 & 24 & 97 & 37 & 60 \\
\hline Sabará & 25.081 & 644 & 24.437 & 35.970 & 1.718 & 34.251 \\
\hline Santa Luzia & 35.828 & 1.614 & 34.214 & 45.549 & 2.898 & 42.651 \\
\hline São Joaquim de Bicas & 420 & 72 & 348 & 636 & 161 & 474 \\
\hline São José da Lapa & 1.537 & 149 & 1.389 & 2.843 & 191 & 2.652 \\
\hline Sarzedo & 1.690 & 132 & 1.558 & 2.988 & 360 & 2.628 \\
\hline Taquaraçu de Minas & 39 & 31 & 8 & 123 & 40 & 83 \\
\hline Vespasiano & 12.899 & 1.111 & 11.788 & 23.308 & 2.634 & 20.675 \\
\hline Total & 266.501 & 39.544 & 226.957 & 382.076 & 69.872 & 312.204 \\
\hline
\end{tabular}

Source: IBGE. Demographic Censuses of 2000 and 2010.

\section{FIGURE 2}

Ratio between reverse commuting (RC) and traditional commuting (TC) in the Metropolitan Region of Belo Horizonte, based on flows from and to Belo Horizonte - 2000-2010
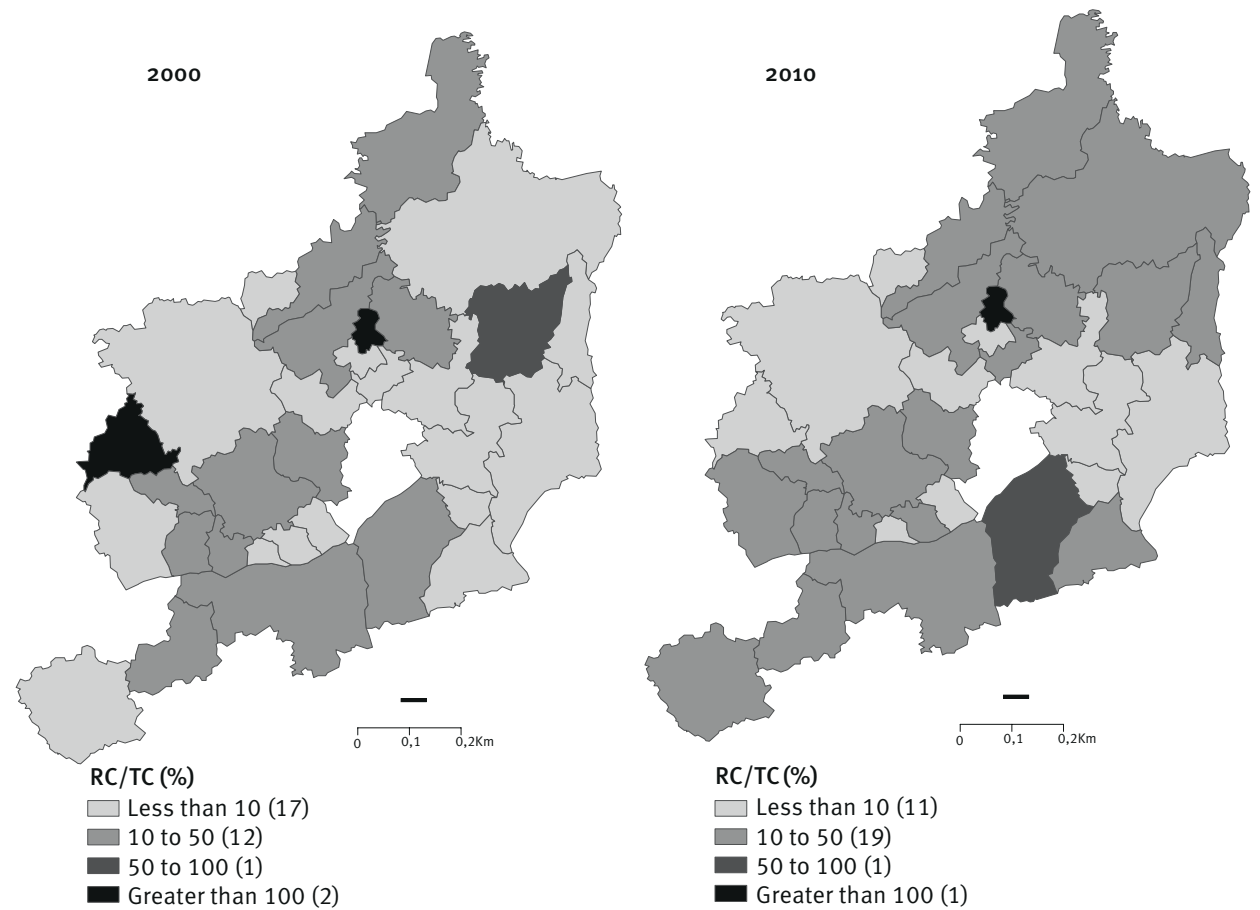

Source: IBGE. Demographic Censuses of 2000 and 2010. 
Given the evidence analyzed to date, what can be said regarding the people living in Belo Horizonte who reverse commute toward the metropolitan periphery? The collection of graphs in Figure 3, identifying the five main occupations of those who commute to work or study in Belo Horizonte, helps to partially answer this question for six municipalities with highest RC flow.

FIGURE 3

Distribution of main occupations of the population residing in Belo Horizonte in 2010 who commuted daily to worked/studied in Contagem, Betim, Nova Lima, Ribeirão das Neves, Santa Luzia, or Vespasiano

$\mathrm{BH}=>$ Contagem

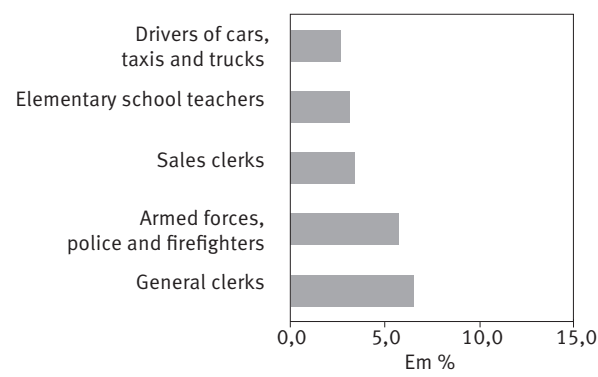

$\mathrm{BH}=>$ Betim

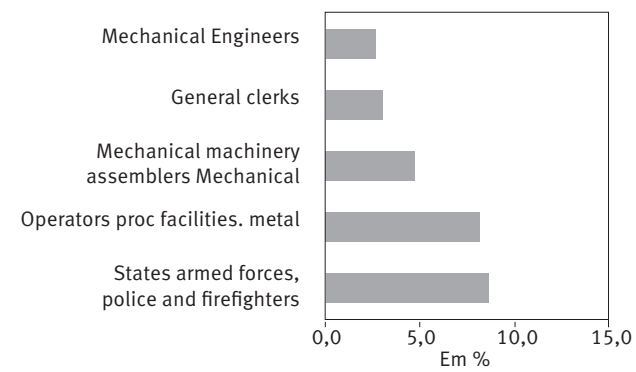

BH $=>$ Nova Lima

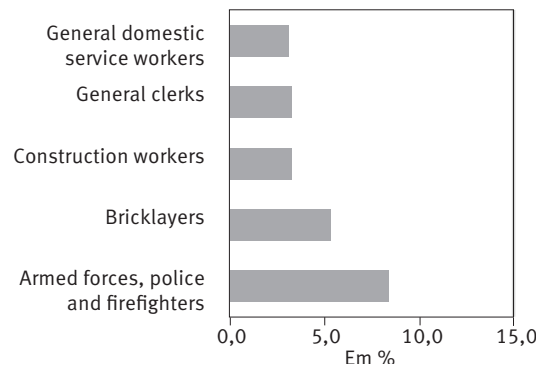

BH $=>$ Ribeirão das Neves

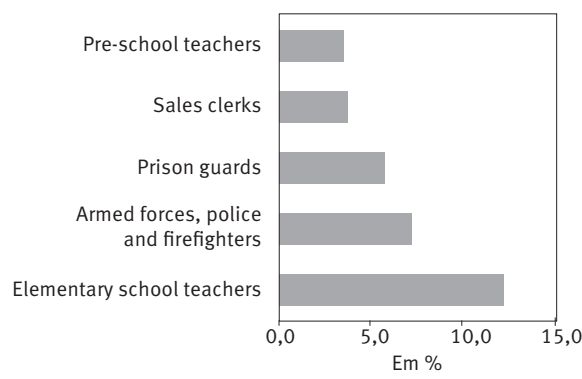

BH $\Rightarrow$ Santa Luzia

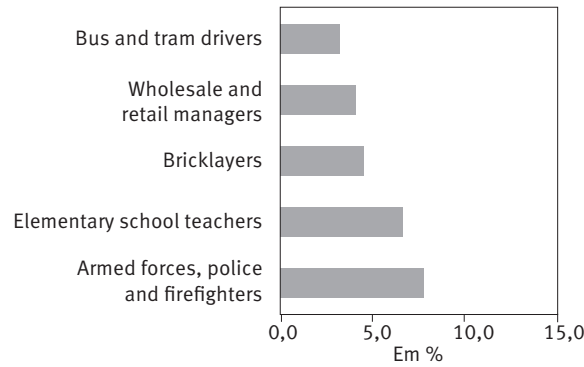

BH $\Rightarrow$ Vespasiano

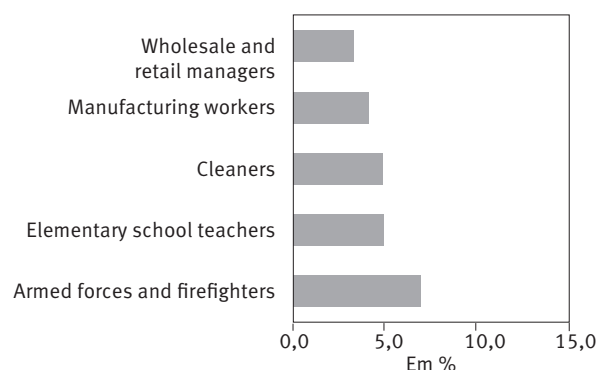

Source: IBGE. Demographic Censuses of 2000 and 2010.

Note: The information of occupation refers to the week of July 25-31, 2010, as defined in the 2010 Demographic Census. 
For the municipalities in which many industrial plants are located - Contagem, Betim, and Santa Luzia - the occupations of those who reverse commute are mainly office clerks, members of the armed forces, store clerks, skilled workers (Betim), elementary school teachers and cleaners. For the other three municipalities, Ribeirão das Neves, Vespasiano, and Nova Lima, the leading occupations are elementary teachers, members of the armed forces, prison guards (Ribeirão das Neves), construction workers, and cleaners.

In short, a significant portion of those who live in Belo Horizonte and who reverse commute to work (more than study) in the metropolitan periphery do so to those municipalities that stand out for generating jobs in the industrial sector, such as Contagem and Betim, or for expansion that demands construction workers, such as Nova Lima and Santa Luzia. However, it is primarily in the tertiary sector where there are more occupations that require medium-skilled workers, such as elementary school teachers, police officers, and sales clerks.

\section{Final considerations}

Since the 1980s, the possible effects of the population's spatial deconcentration and dispersion have attracted the attention of many Brazilian researchers. After decades in which the country experienced a strong concentration of population and economic activities in the major metropolises of the Southeast, there is evidence of a shift away from the past concentrative pattern. Although Brazil's socioeconomic reality is different from that of developed countries, various studies have attempted to evaluate the hypothesis of "reverse polarization" in Brazil. The debate continues, although there is much evidence to suggest that there is, if not a complete deconcentration in the classic mold of developed countries, at least a significant increase in commuting in the country's main cities and growth of many spaces outside the metropolitan cores.

Regardless, research is still emerging that examines the diversity of the population's movements within this type of analysis, whether taking the classical definition of migration into account or considering commuting. In this context, the Metropolitan Region of Belo Horizonte comprises a unique space. Halfway through the last century, the state capital had just over 350,000 inhabitants. In less than fifty years Belo Horizonte experienced a strong surge of population growth and a subsequent deceleration, largely the result of a reversal of center-periphery net migration. From that moment on, several of the metropolitan area's urban centers were strengthened, and they began to exhibit population growth levels well above those of the core, fed by increasing migration. If the population's spatial dispersion does not completely explain spatial deconcentration, as suggested by the regional economy, the signs that many spaces outside the metropolitan core are gaining economic autonomy have multiplied.

The evidence presented here goes beyond the successes of Contagem and Betim municipalities, which are important centers of the Minas Gerais industrial park's expansion; 
it also brings to light the role played by municipalities on the MRBH's north axis, such as Ribeirão das Neves, Santa Luzia, and Vespasiano. One way to evaluate changes in the centrality of the metropolitan area is to analyze the population's daily movements. Based on the 2000 and 2010 censuses, it was possible to identify a significant increase in the proportion of daily residence-to-work/study flows from the municipalities of the periphery towards the metropolitan core, which in 2010 involved almost 70,000 people (highlighting the cases of Betim/Contagem in terms of volume, and Confins for its ratio). Associated with this change, many of the municipalities of the periphery had a significant growth in flows of residents traveling away from Belo Horizonte, especially skilled workers in the urban tertiary sector and public service jobs (teachers and members of the military).

Although the results presented in this paper are database derived from just two decades, requiring attention to possible conclusions about general trends, there are signs of consolidation of new centralities in the metropolitan periphery of Belo Horizonte, which have attracted more than a few workers and students coming from the core. However, more research is necessary on each municipality, incorporating the results obtained of future censuses and analyzing the reality of other metropolitan areas in Brazil, especially São Paulo and Rio de Janeiro.

\section{References}

ANTICO, C. Deslocamentos pendulares nos espaços sub-regionais da Região Metropolitana de São Paulo. In: XIV ENCONTRO NACIONAL DE ESTUDOS POPULACIONAIS. Anais... Caxambu: Abep, 20 a 24 de setembro de 2004.

ARANHA, V. Mobilidade pendular na metrópole paulista. Revista São Paulo em Perspectiva, v. 19, n. 4, p. 96-109, out./dez. 2005.

AZZONI, C. Indústria e reversão da polarização no Brasil. Ensaios Econômicos, n. 58, 1986.

BRITO, F.; SOUZA, J. Expansão urbana nas grandes metrópoles: o significado das migrações intrametropolitanas e da mobilidade pendular na reprodução da pobreza. São Paulo em Perspectiva, v. 19, n. 4, p. 48-63, out./dez. 2005.

CANO, W. Raízes da concentração industrial em São Paulo. 2. ed. São Paulo: TA Queiroz, 1977.

DINIZ, C. C. Desenvolvimento poligonal no Brasil; nem desconcentração, nem contínua polarização. Nova Economia - Revista de Ciências Econômicas da UFMG, v. 31, n. 11, p. 35-64, 1993.

GREENWOOD, M. Migrações internas nos Estados Unidos; uma revisão da literatura. In: MOURA, A. M. (Coord.). Migração interna; textos selecionados. Fortaleza: Banco do Nordeste do Brasil, 1980. p. 733-77.

LOBO, C. Dispersão espacial da população nas regiões de influência das principais metrópoles brasileiras. Tese (Doutorado) - Universidade Federal de Minas Gerais, Departamento de Geografia, Belo Horizonte, 2009.

LOBO, C.; CARDOSO, L.; MATOS, R. Mobilidade pendular e centralidade espacial: considerações sobre o caso da Região Metropolitana de Belo Horizonte. In: XXIII ANPET - Congresso de Pesquisa e Ensino em Transportes. Anais... Vitória-ES, 2009. 
LOBO, C.; MATOS, R. Migrações e a dispersão espacial da população nas regiões de influência das principais metrópoles brasileiras. Revista Brasileira de Estudos de População, v. 28, n. 1, p. 81-101, 2011.

MARTINE, G. A redistribuição espacial da população brasileira durante a década de 80 . Brasília: Ipea, 1994 (Textos para discussão, 329). Migração e metropolização. São Paulo em Perspectiva, v. 1, n. 2, 1987.

MATOS, R. Dinâmica migratória e desconcentração da população na macrorregião de Belo Horizonte. Tese (Doutorado) - Universidade Federal de Minas Gerais, Cedeplar, Belo Horizonte, 1995 a.

Questões teóricas acerca dos processos de concentração e desconcentração da população no espaço. Revista Brasileira de Estudos de População, v. 12, n. 1/2, p. 35-58, 1995 b.

MATOS, R.; FERREIRA, R. N. Inserção ocupacional de emigrantes das Áreas Metropolitanas de São Paulo e Rio de Janeiro. Revista Brasileira de Estudos de População, v. 21, n. 1, p. 83-100, 2004.

MATOS, R.; BAENINGER, R. Migração e urbanização no Brasil: processos de concentração e desconcentração espacial e o debate recente. Cadernos do Leste, v. 1, n. 1, p. 7-44, 2004.

MOURA, R. et al. Movimento pendular e perspectivas de pesquisas em aglomerados urbanos. São Paulo em Perspectiva, v. 19, n. 4, p. 121-133, out./dez. 2005.

NEGRI, B. Concentração e desconcentração industrial em São Paulo (1880-1990). Campinas: Ed. Unicamp, 1996.

OJIMA, R.; SILVA, B. R.; PEREIRA, R. H. M. A mobilidade pendular na definição das cidades-dormitório: caracterização sociodemográfica e novas territorialidades no contexto da urbanização brasileira. In: VIII ENCONTRO NACIONALSOBRE MIGRAÇÕES. Anais... Belo Horizonte, 2014, p. 1-24.

PATARRA, N. Dinâmica populacional e urbanização no Brasil: período pós-30. In: FAUSTO, B. História geral da civilização brasileira: o Brasil republicano. São Paulo: Difel, 1984. t. 3, v. 4, p. 247-268.

REDWOOD III, J. Reversion de polarizacion, ciudades secundarias y eficiencia en el desarrollo nacional: una vison teorica aplicada al Brasil contemporaneo. Revista Latinoamericana de Estudios Urbanos Regionales, v. 11, n. 32, dez. 1984.

RICHARDSON, H. Polarization reversal in developing countries. The Regional Science Association Papers, v. 45, Nov. 1980.

RIGOTTI, J. I. R. Técnicas de mensuração das migrações a partir de dados censitários: aplicação aos casos de Minas Gerais e São Paulo. Tese (Doutorado em Demografia) - Cedeplar, Universidade Federal de Minas Gerais - UFMG, Belo Horizonte, 1999.

RIGOTTI, J. I. R.; RODRIGUES, J. N. Distribuição espacial da população na região Metropolitana de Belo Horizonte. In: IX ENCONTRO DE ESTUDOS POPULACIONAIS. Anais... Caxambu: Abep, 1994. p. 435-456.

SINGER, A. Brasil, junho de 2013, classes e ideologias cruzadas. Novos Estudos Cebrap, n. 97, p. 23-40, 2013.

TASCHNER, S. P.; BÓGUS, L. M. M. Mobilidade espacial da população brasileira: aspectos e tendências. Revista Brasileira de Estudos de População, v. 3, n. 2, p. 87-129, jul.-dez. 1986.

TOWNROE, P.; KEEN, D. M. Polarization reversal in the state of São Paulo, Brazil. Journal of the Regional Studies Association, v. 18, n. 1, Feb. 1984. 


\section{About the authors}

Carlos Lobo is PhD in Geography. Associate Professor in the Department of Geography at the Geoscience Institute, Universidade Federal de Minas Gerais.

Ralfo Matos is PhD in Demography. Full professor in the Department of Geography at the Geoscience Institute, Universidade Federal de Minas Gerais.

Leandro Cardoso is PhD in Geography. Associate Professor in the Department of Transport Engineering and Geotechnics, School of Engineering, Universidade Federal de Minas Gerais.

Lídia Comini is undergraduate student in Geography at the Universidade Federal de Minas Gerais. She holds a scientific initiation scholarship from FAPEMIG.

Guilherme Pinto is PhD student in Geography at the Universidade Federal de Minas Gerais. He holds a doctorate scholarship from CNPq.

\section{Contact address}

Carlos Lobo

Rua Domingos Garcia, 939, apto. 20, São João Batista

31520-200 - Belo Horizonte-MG, Brasil

\section{Resumo}

Comutação ampliada na Região Metropolitana de Belo Horizonte: evidências à mobilidade pendular inversa

As grandes cidades brasileiras, sobretudo aquelas com rápido crescimento demográfico observado a partir de meados do século passado, vêm apresentando nas últimas décadas significativos sinais de dispersão da população em suas periferias. 0 estudo da redistribuição espacial da população na Região Metropolitana de Belo Horizonte (RMBH) aponta para essa assertiva. Nesse processo aumentam os níveis de comutação urbana e a mobilidade pendular é um indicador relevante para aferir graus de integração no interior da metrópole. Nesse artigo avalia-se a magnitude atual e as principais características da denominada pendularidade inversa, caracterizada pelos deslocamentos diários da população residente não na periferia, mas sim no núcleo. São escrutinados os fluxos do core metropolitano em direção aos municípios periféricos. Para tanto, foram utilizados os microdados amostrais dos Censos Demográficos de 2000 e 2010 referentes aos municípios da RMBH, por meio de combinações das variáveis "município de residência" e "município de trabalho/estudo". Os resultados indicam um crescimento tanto em termos absolutos como relativo da pendularidade inversa. Quando se compara esse fluxo com a pendularidade tradicional - (periferia/centro), os valores relativos são consideráveis. Em alguns casos, essa relação atinge valores muito altos, como Confins (município onde se localiza o aeroporto internacional), ou nos municípios de conurbação relativamente antiga: Nova Lima e Betim.

Palavras-chave: Mobilidade pendular. Região Metropolitana de Belo Horizonte. Dispersão espacial da população. 


\section{Resumen}

Conmutación ampliada en la Región Metropolitana de Belo Horizonte: evidencias de la movilidad pendular inversa

Las grandes ciudades de Brasil, especialmente aquellas que han experimentado un crecimiento rápido de la población desde mediados del siglo pasado, han presentado en las últimas décadas señales significativas de dispersión de la población en sus periferias. El estudio de la redistribución espacial de la población en la Región Metropolitana de Belo Horizonte (RMBH) apunta en esa dirección. En este proceso aumentan los niveles de conmutación urbana, y la movilidad pendular es un indicador relevante para estimar grados de integración dentro de la metrópoli. En este artículo se evalúan la magnitud actual y las principales características de la llamada pendularidad inversa, que se caracteriza por los desplazamientos diarios de la población residente en el centro, no en la periferia. Se examinaron los flujos desde el núcleo metropolitano hacia los municipios periféricos. Para esto, se utilizaron los microdatos muestrales de los censos demográficos de 2000 y 2010 de los municipios de la RMBH, por medio de combinaciones de las variables "municipio de residencia” y “municipio de trabajo/estudio". Los resultados revelan un aumento de la pendularidad inversa tanto en términos absolutos como relativos. Cuando se compara este flujo con la pendularidad tradicional (periferia / centro), los valores relativos son considerables. En algunos casos esta relación alcanza valores muy altos, como en Confins, municipio en el que se encuentra el aeropuerto internacional, o en los municipios de conurbación relativamente antigua, como Nueva Lima y Betim.

Palabras clave: Movilidad pendular. Región Metropolitana de Belo Horizonte. Dispersión espacial de la población.

Recebido para publicação em 25/10/2014

Recomendado para publicação em 20/02/2015

Aceito para publicação em 15/07/2015 
